\title{
Aristotelés o původu obce
}

\section{Jakub Jinek}

\section{Úvod}

Význam klasické otázky po původu polis zdaleka přesahuje horizont klasických bádání a dotýká se i základů naší moderní politické identity. Její inspirativnost bývá shledávána zejména na pozadí rozdílu mezi klasickým a moderním pojetím státu, ${ }^{\mathrm{i}}$ reprezentovaným Aristotelem na jedné straně a T. Hobbsem na straně druhé. V tomto výkladovém schématu se zdůrazňuje zejména otázka po charakteru polis jakožto bud' přirozené, anebo umělé entity. ii Avšak ukazuje se, že porozumět slovu ,přirozené“, jak je Aristotelés v této souvislosti používá, je krajně obtížné a zdá se nutné - soudě alespoň podle většiny moderních interpretací - zahrnout do úvahy jiná Aristotelova díla, at' už metafyzická, či biologická. V první řadě se nabízí chápat přirozenost obce jako titul náležející přirozenému jsoucnu, první úsia. iii Toto chápání vede $\mathrm{v}$ radikálnější podobě $\mathrm{k}$ tezi, že obec je nějak nadřazena

\footnotetext{
${ }^{\mathrm{i}}$ Srv. L. Strauss, Eseje o politické filosofii, Praha 1995.

ii D. Keyt, „Three Basic Theorems in Aristotle's Politics“, in: D. Keyt - F. D. Miller, jr. (vyd.), A Companion to Aristotle's Politics, Oxford - Cambridge (Mass.) 1991, str. 118-141.

iii Viz A. B. Hentschke, Politik und Philosophie bei Platon und Aristoteles, Frankfurt a. M. 1971; M. Riedel, „Politik und Metaphysik bei Aristoteles“, in: týž, Metaphysik und Metapolitik, Frankfurt a. M. 1975.
} 
jednotlivci a v extrémním př́ípadě vede $\mathrm{k}$ organicistickému pojetí státu. ${ }^{\text {i }}$ Jiným pokusem je chápat politickou přirozenost člověka jako přirozenost rozumové bytosti odkázané na obec, což je zase linie uvažování, která se přiklání $\mathrm{k}$ tradici přirozeného zákona. ${ }^{\mathrm{ii}}$

W. Kullmann, který předložil zřejmě dosud nejdůkladnější analýzu teze o politické přirozenosti člověka, se energicky obrací především proti prvnímu výkladu a upozorňuje, že primárním Aristotelovým ohledem není polis, nýbrž člověk. Všechny významné Aristotelovy výroky o poměru člověka a polis se podle něj nevztahují na polis jakožto přirozené jsoucno, které by „dorůstalo“ do své fysis, nýbrž na člověka v jeho politické přirozenosti. To však také znamená - a to je Kullmannova výhrada vůči druhému zmiňovanému výkladu -, že tyto výroky se netýkají obecně chápané lidské duchovosti, nýbrž jsou podle něj vlastně antropologickými výroky, začleňujícími člověka do systému živočišných druhů a upozorñující na jeho specifickou biologickou přirozenost kooperativní bytosti. Kullmann se domnívá, že nechat Aristotela promluvit o přirozenosti polis $\mathrm{v}$ jeho vlastních

\footnotetext{
${ }^{\mathrm{i}} \mathrm{V}$ této podobě se pak tvrzení, že polis je něčím přirozeným, stává předmětem Hobbesovy antiteze, podle níž je naopak néčím umělým. Srv. R. Mulgan, Aristotelova politická teorie, Praha 1998, str. 40-48.

ii L. Strauss, Natural Law and History, Chicago 1953, kap. 4; J. Ritter, Metaphysik und Politik. Studien zu Aristoteles und Hegel, Frankfurt a. M. 1969; G. Bien, Die Grundlegung der politischen Philosophie bei Aristoteles, Freiburg i. B. - München 1973.
} 
pojmech vyžaduje ostré odlišení dvojího kontextu argumentace pomocí prrirozenosti: zatímco $\mathrm{v}$ případě člověka je myšlena $\mathrm{v}$ přísném slova smyslu, $\mathrm{v}$ př́padě polis je řeč o přrirozenosti pouze metaforická.

Kullmannova kritika výkladu obce jako substance a jeho rekonstrukce antropologických předpokladů Aristotelovy politiky je jistě hermeneuticky oprávněná. Přesto se nabízí otázka, zda jeho výklad zdůrazňující primát antropologie neupadá do protivné krajnosti. ${ }^{\text {ii }}$ M. Mráz v předmluvě ke svému překladu Politiky staví Aristotelovy teze do širšího kontextu antického politického myšlení až k Polybiovi a upozorňuje na to, že Aristotelés si byl rovněž vědom určitých zákonitostí ve vývoji polis, a že tedy má povědomí o růstu, vzmachu a úpadku obce. ${ }^{\text {iii }}$ Svoje zjištění však Mráz nijak dále nekomentuje a nevysvětluje ani to, jak se to má se vztahem dvou různých hledisek (antropologického a vývojového) navzájem. Pokusím se v následujícím rozvést Mrázovu intuici o platnosti obojího kontextu původu obce $\mathrm{z}$ hlediska intenzivního pojmu

\footnotetext{
${ }^{\mathrm{i}}$ W. Kullmann, „Der Mensch als politisches Lebewesen bei Aristoteles“, in: Hermes, 108, 1980, str. 419-443; citováno podle revidovanéh angl. překladu: „Man as a Political Animal in Aristotle“, in: D. Keyt - F. D. Miller, jr. (vyd.), A Companion to Aristotle's Politics, Oxford - Cambridge (Mass.) 1991, str. 94 117.

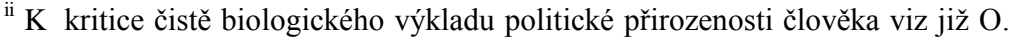
Höffe, „Grundaussagen über den Menschen bei Aristoteles“, in: Zeitschrift für philosophische Forschung, 30, 1976, str. 227-245, zvl. pozn. 9.

iii M. Mráz, „Úvod“, in: Aristotelés. Politika I, Praha 1999, str. 26.
} 
politiky. Domnívám se, že intence otázky po původu polis, tak jak ji Aristotelés komplexně klade v I. knize Politiky, nemírí ani pouze $\mathrm{k}$ charakteru polis (a souvisejícím problémům klíčovým pro novověkou politickou teorii, napřr. k problému zákona, povinování či autonomie), ${ }^{\mathrm{i}}$ ani pouze $\mathrm{k}$ politické přirozenosti člověka, nýbrž především k političnu samému. Je pokusem o stanovení samostatného významu adjektiva „politický“, vyznačujícího předmět zkoumání nové vědy, kterou Aristotelés v Politice zakládá a která není antropologií, biologií ani ontologií. Kullmannovo upozornění na význam antropologicko-biologické inspirace Aristotelovy Politiky včetně četných intertextuálních poukazů považuji za cenný, ale pouze pomocný argument, který nesmí stát $\mathrm{v}$ cestě zkoumání politična ve vlastním smyslu, a to ve svébytném kontextu I. knihy Politiky.

\section{Topos původu obce}

Výklad o původu obce je na začátku druhé kapitoly I. knihy Politiky uveden úkolem zkoumat věci, jak od počátku vyrůstají (ex archés fyomena, 1252a24). Tato formulace může překvapit čtenáře úvodní kapitoly I. knihy, na jejímž konci byla ohlášena analýza obce (kata tén hyfégémenén methodon, 1252a17-18). Jako by se Aristotelés namísto

\footnotetext{
i Jak důvtipně ukazuje D. J. Allan, Individual and State in the Ethics and Politics, in: R. Stark (vyd.), La Politique d'Aristote, Genéve 1965, str. 55-85.
} 
logické analýzy věci chtěl obrátil k biologickému či historickému výkladu. ${ }^{\mathrm{i}} \mathrm{O}$ metodický zvrat se však nejedná - analyzovat polis znamená vyložit ji od počátku, tj. vysvětlit její povahu $\mathrm{z}$ toho, jak „rostla“. To odkazuje k tradičnímu toposu původu a vzniku obce. Tato metodická poznámka tedy neimplikuje ani organistickou teorii, ani historismus; lze ji číst jako zkratku ohlašující tradiční žánr a topiku, jíž chce Aristotelés kriticky navázat na dosavadní myslitele. Lze předpokládat, že Aristotelés měl před očima zejména dvě základní pojetí původu obce lišící se v otázce, zda obec představuje něco historicky vzniklého, anebo přirozeně daného. První pojetí reprezentuje Démokritos, přírodní věda, historiografie a sofisté, zejm. Protágoras; druhé pojetí zastává Platón.

Démokritos je přesvědčen o konvencionalitě mnoha věcí, např. řeči, barev či chutí, ${ }^{\text {ii }}$ a přestože se nedochoval zlomek, který by totéž výslovně ř́kal o obci, ${ }^{\text {iii }}$ Démokritovu inklinaci k tezi o konvencionalitě státu potvrzuje jeho pojetí původu kultury. Kultura se podle něj objevuje jako lidský vynález podnícený tlakem nutnosti, která lidi „učí“ osvojit

\footnotetext{
i Zde také nasazují moderní interpretace, které v Aristotelovi chtějí vidět líčení vývoje obce jakožto individuální entity po vzoru přirozené úsia. Viz pozn. 3.

ii Démokritos, $D K 68$ B 9, 10, 26, 125.

iii Tezi o smluvním charakteru státu však nacházíme u jeho následovníka Epikúra (Kyr. dox. 31-38). Proto lze považovat za velmi pravděpodobné, že tato myšlenka byla př́tomna již u Démokrita; viz T. Gomperz, Griechische Denker, I: Die Anfänge. Von der Metaphysik zur positiven Wissenschaft. Das Zeitalter der Aufklärung, str. 317.
} 
si určité dovednosti. ${ }^{i}$ Přesvědčení, že člověk žil původně jako divoch a teprve postupně byl donucen vytvořit kulturu, která je oproti jeho nedostatečnosti jakousi náhradou přestože jeho zárodek byl v podobě prométheovského mýtu prrítomen v řecké kultuře odpradávna -, lze v kontextu 5.-4. století nejspíš považovat za revoluční, takže můžeme hovořit o osvícenském prvku řeckého myšlení. ${ }^{\text {ii }}$ Jeho druhou větví jsou prírodovědná a historická zkoumání. V hippokratovském spise $O$ starověkém lékařství, kap. III, nacházíme podobnou tezi o původu kultury: lidé se $\mathrm{v}$ dávných dobách stravovali jako zviŕata a teprve nutnost je donutila vynalézt umělou potravu a tu dále upravovat. ${ }^{\mathrm{iii}} \mathrm{U}$ Thukydida narážíme na ambiciózně založené líčení řecké prehistorie, z něhož vyplývá, že řecký způsob života v polis je vlastně vzmachem z původního, nuzného a všeobecného barbarství. $^{\text {iv }}$

\footnotetext{
${ }^{i}$ Diodóros, Bibl. hist. I,8,7-9. Viz ř. 9: „Hovoříme-li všeobecně, byla to sama potřeba, která se stala učitelkou lidí a poskytovala náležitě ve všem poučení přirozeně obdařené bytosti, jež dostala universální pomocníky: ruce, rozum a bystrost duše."

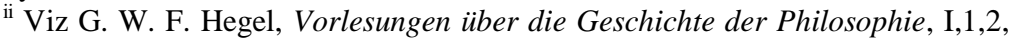
in: Werke in zwanzig Bänden, vyd. E. Moldenhauer - K. M. Michel, 18, Frankfurt a. M. 1979 (česky: Dějiny filosofie, přel. J. Cibulka - M. Sobotka, Praha 1961), str. 410.

iii Viz J. Daneš, Úvod, in: týž aj. (vyd.), Corpus Hippocraticum (v tisku), kap. III.

iv Thúkydidés, Hist. I,2-19. Zajímavý je v tomto směru zájem, který o Thúkydidovo „politické myšlení“ projevil Thomas Hobbes. Srv. L. Strauss, Obec a člověk, Praha 2007, str. 152-153.
} 
Součástí „řreckého osvícenství“ je rovněž sofistika zmíněnou tezi o původním zvířecím stadiu lidstva zastává např. Kritias. ${ }^{i}$ Nejvýznamnější je ale bezpochyby Protágorovo líčení vývoje kultury a obce, jež nacházíme ve stejnojmenném Platónově dialogu (320c-323a). ${ }^{\text {ii }}$ $\mathrm{S}$ předcházejícími autory se shoduje $\mathrm{v}$ tom, že člověk je „nahé, bosé, nekryté a neozbrojené“ stvoření, které původně nežilo v obci a základní věci k životu si muselo teprve vynalézt. ${ }^{\text {iii }}$ Tato představa je sice méně atheistická, nebot' umění nevzniklo spontánně působením nutnosti, ale je to dar bohů (322a), shoduje se však v tom podstatném: stát vzniká až po určité předběžné fázi, v níž lidé žijí apoliticky. Společný je rovněž osvícenský étos, podle něhož předvedený vývoj je pokrokem k lepšímu.

U Platóna nacházíme několik různých líčení původu obce. Nejznámější je bezpochyby II. kniha Ústavy, kde Sókratés se svými partnery zakládá obec „, řeči“ (logó). Tato obec stojí na existenční nutnosti (chreia) dané lidskou nedostatečností a je určena jejím odstraňováním, přesněji řečeno úkoly, které v tomto směru plní občané-řemeslníci (369d nn.). Výslovně se pritom od počátku jedná o polis, nikoli sdružení jedinců, kteří by polis teprve tlakem nutnosti

\footnotetext{
${ }^{\text {i }}$ Srv. též Kritias, $D K 88$ B 25.

ii Protágorův mýtus je zřejmě autentický - názor, že jde o pozici Platónovu, nelze přijmout vzhledem $\mathrm{k}$ tomu, že $\mathrm{v}$ mýtu řevládají prodemokratické prvky.

${ }^{i i i}$ F. L. Lisi, Einheit und Vielheit des platonischen Nomosbegriffes, Königstein 1985, str. 294.
} 
vytvořili. Nejde o historické líčení ve smyslu geneze nové skutečnosti, nýbrž o fenomenologicko-strukturní analýzu (srv. 369a5-8, c9) funkcionálních základů lidského soužití. ${ }^{i}$ Výklad tedy představuje jasnou distanci od „osvícenských“ progresistických koncepcí - polis existující od počátku a založená na lidské nedostatečnosti je antropologickou konstantou.

Podobně ahistorické líčení se objevuje v Ústavě v VIII. a IX. knize. ${ }^{\text {ii }}$ Popis zvratů a stálého úpadku obcí či ústav nemůžeme považovat za sukcesi ústav ve smyslu Polybiově či Ciceronově, nýbrž jde o spekulativní líčení vývojové dynamiky př́tomné v lidské psyché. Př́tomna je zde nicméně myšlenka o jistých strukturních zákonitostech vzestupu a pádu obcí.

Historické líčení původu obce $\mathrm{v}$ kontextu kosmologických cyklů nabízí mýtus dialogu Politikos (268d-274e). Situace př́mého božského ovládání lidí v Kronově epoše představuje protipól výkladu II. knihy Ústavy, nebot' líčí stav materiální hojnosti bez práce. ${ }^{\text {iii }}$ Ani zde nemůže být řeč o ustavení obce, nebot' určitá forma lidského spolužití pod společnou vládou, totiž ,podle rodů a stád“" (kata gené kai agelas, 271d6), existuje i v situaci maximální jednoty př́mého božského řízení světa. Přestože

\footnotetext{
i Tamt., str. 297.

ii Tamt., str. 298; srv. str. 305.

iii Srv. Platón, Leg. 713c2-4; srv. Hésiodos, Erg. 117 n.
} 
nelze jednoznačně říci, zda jde za Kronovy vlády o skutečnou polis, či nějaký její rudiment, ${ }^{i}$ je zřejmé, že celková intence pasáže je antiindividualistická a specificky „antiosvícenská“": i v situaci naprosté božské jednoty budou lidé žít organizovaně pospolu. ${ }^{\text {ii }}$ Obec a kultura nevzniká ani v Diově ére. Techné je sice - po kosmické katastrofě - dána lidem jako božský dar (274c-e), avšak nevyvíjí se lidským úsilím k dokonalosti, protože je již dokonalá; při jejím osvojení nejde o objevení, nýbrž spíše o rozpomínání.

Poněkud odlišný je paralelní výklad dialogů Timaios (21e-25d) a Kritias (108d-121c) o dávných Athénách a Atlantidě. V těchto obcích nevládne bůh, nýbrž uskutečňuje se velmi dobrá lidská vláda (zřejmě odpovídající vládě filosofů popsané v Ústavě). Podstatným prvkem líčení je nejen to, že periodické katastrofy (oproti kosmické katastrofě v Politikovi menšího, sublunárního dosahu) znovu a znovu obnovovaly civilizační cyklus, vedoucí od původních nuzných - nikoli však zcela nekulturních podmínek k postupnému zdokonalení, a to pomocí darů ochranných božstev (24b, d; 109d2), ale rovněž implicitní

\footnotetext{
i Nelze jej naopak ztotožnit s ideálním státem, nebot' pod Kronovou vládou výslovně neexistuje politeia, ani jej nelze klást významem až za ideální stát, nebot' lidské uspořádání nemůže být lepší než božské.

ii Tento výklad je potvrzen v paralelní pasáži IV. knihy Zákonů (713e-714a), která líčí vládu Kronovu jako ideální stav, který je třeba současným politickům napodobovat.
} 
předpoklad, že od popisované doby došlo k zhoršení lidských povah a obcí až k dnešnímu stavu.

Katastrofa podobného menšího rozsahu a geneze následného lidského spolužití je popisována v Zákonech III. Ani zde dávní lidé nežijí jako zvířata, nýbrž mají přiměřeně materiálně zajišstěnou kulturu (679a; srv. ale Criti. 110a). Potřeba (chreia) zákonodárství nevzniká - jako v Protagorovi (322b) - z ohrožení života, nýbrž proto, že to nutně vyžaduje (anankaion) sejití se velkého počtu lidí (Leg. 681c7), jejichž zvyky musí být sjednoceny. Předmětem dalšího výkladu je pak velmi různorodý osud obcí, kdy jsou kontrastovány Persie a Athény, které pro krajnost svého zrrízení stále upadají, a Sparta, jejíž smíšené zř́zení umožnilo zachovat alespoň částečně stabilitu obce.

U Platóna lze tedy nalézt jak strukturně-logické pojetí obce, tak její historický výklad. Přes odlišnost kontextu různých líčení lze pozorovat jistou výkladovou konstantu, ${ }^{\mathrm{i}}$ jež vyvstane především ve srovnání $\mathrm{s}$ dvěma hlavními myšlenkami předchozí tradice řeckého osvícenství: 1) člověk je původně deficientní bytostí a kultura je mu teprve přidána; 2) věci se s vývojem zlepšují. Platón napadá zejména první tezi - podle něj neexistuje nepolitická přirozenost člověka, nebot' obec (nebo nějaká

\footnotetext{
i Otázku, zda se jedná o „filosofii dějin“, přitom nechávám stranou. Srv. k tomu k tomu K. Gaiser, Platon und die Geschichte, Stuttgart - Bad Cannstaat 1961.
} 
jiná forma organizovaného soužití) je antropologickou konstantou. Druhá teze však není Platónem jednoznačně vyvrácena. Textově lze vykázat, že Platón není - jak se mu často podsouvá - zastáncem výkladu o nutném civilizačním úpadku. Úpadek obcí je sice dost obvyklý, není však fatalisticky nezměnitelný, nýbrž jej lze odvrátit, jak ukazuje př́klad Sparty v III. knize Zákonů. Tato možnost je dokonce předpokladem pro celý zákonodárný podnik tohoto dialogu (viz Leg. IV). Je tedy spíše o Platónovu revizi než o antitezi osvícenského optimismu.

Toto je konstelace, do které vstupuje I. kniha Aristotelovy Politiky jako pokus o ambiciózní syntézu této tradiční topiky. Aristotelés se bude v první otázce shodovat s Platónem, $\mathrm{v}$ druhé bude tíhnout $\mathrm{k}$ osvícenskému optimismu, ale zároveň nechá v platnosti platónskou ambivalenci možného vývoje $\mathrm{k}$ dobrému i upadlému. Jeho syntéza bude chtít zahrnout obě intuice a prritom se vyhnout dvěma nebezpečím, která sice Aristotelés výslovně netematizuje, ale o nichž lze na základě jiných míst předpokládat, že určují jeho úvahu:

1) Historické lićcní je ze své podstaty vydáno nahodilosti. Historie je tím dokonce méně fillosofická než básnictví, jak zní známá Aristotelova průpověd' (Poet. 9,1451b6 nn.), nebot' to, co není obecné, se nemůže stát předmětem vědy (De an. II,5). Můžeme se proto ptát po 
legitimitě tvrzení o stálém směřování obce $\mathrm{k}$ lepšímu, jež je vždy vydáno nebezpečí ideologické obhajoby př́tomného stavu. ${ }^{\text {i }}$

2) Také logicko-antropologická analýza obce, na niž klade důraz Platón, má - přinejmenším v Aristotelově chápání - své nebezpečné důsledky. Pokud je političnost člověka věcí stálé a predikovatelné struktury, stačí k politické činnosti tuto strukturu dostatečně poznat. Správně usměrňovaná polis pak bude nevyhnutelně směřovat k modelu obce z Platónovy Ústavy včetně jeho z Aristotelova hlediska - rigidní hierarchické struktury, v níž vládcem je nutně ten, kdo správně pochopil původ a cíl obce a vlády. Tuto podobu zřejmě má specifický Aristotelův výklad Platónova filosofa-krále, proti jehož domnělému důsledku - zpochybnění rozdílů mezi druhy vlád (krále, politika, hospodáře a pána) - se Aristotelés programaticky obrací (viz 1252a7-13).

Aristotelovým programem proto bude vidět neideologicky přirozenou strukturu obce a zároveň její vývoj v čase, který umožní diferenciaci úkolů a vztahů v jejím rámci. V obtížném pokusu o bezrozporné spojení obojího vyvstane specifické Aristotelovo pochopení pro politično.

\footnotetext{
i Srv. M. Schofield, „Ideology and Philosophy in Aristotle's Theory of Slavery”, Slavery”, in: G. Patzig (vyd.), Aristoteles 'Politik, Göttingen 1990, str. 6.
} 


\section{Struktura a dějiny}

Analýza obce vysvětluje existenci politického společenství ze skutečných antropologických základů. Tyto základy mají charakter vztahu: mužské a ženské se sdružují za účelem zplození potomka; přirozeně vládnoucí se sdružuje $\mathrm{s}$ přirozeně ovládaným, a to pro zachování (sotéria) zatímco vládnoucí a panské je schopné myšlením předvídat, ovládané a otrocké je schopné tělesně pracovat (1252a3034).

Užití adjektiv středního rodu („mužské“, „ženské“, „vládnoucí“, „panské“, „ovládané“, „otrocké“) napovídá, že nejde o konkrétní osoby, ${ }^{\mathrm{i}}$ nýbrž o obecné principy, at' už antropologického, či obecně prŕrodního charakteru aplikované pak na člověka. ${ }^{\text {ii }}$ Aristotelés se ptá na

\footnotetext{
${ }^{i}$ Většina moderních interpretů tuto závažnou skutečnost přechází a hovoří automaticky o lidech; viz W. L. Newman, The Politics of Aristotele, II, Oxford 1887, str. 105-106; O. Gigon, Aristoteles, Politik, Zürich - Stuttgart 1971, str. 340; T. J. Saunders, Aristotle: Politics I, II, Oxford 1995, str. 63-64; E. Schütrumpf, Aristoteles. Politik I, Berlin 1991, str. 188; totéž implikují i moderní překlady, včetně Mrázova (Aristotelés. Politika I) (výjimkou je překlad A. Křiže [Praha 1939, 1996²] a F. S. Schwarze [Stuttgart 1989]). Je to věcně nepodložené (i přes Newmannovu [The Politics of Aristotle, str. 106] poznámku $\mathrm{k}$ ř. 30) a je to třeba přičíst na vrub tradici.

ii Tím odpadá svízelná otázka, zda podle Aristotela existují lidé, kteř́ jsou pouze pouze schopni tělesné práce, a pokud ano, zda je existence takových typů lidí slučitelná s jednotným lidským eidos, kterou si kladou např. O. Gigon, Die Sklaverei bei Aristoteles, in: R. Stark (vyd.), La Politique d'Aristote, Genéve 1965, str. 248-249; N. S. Smith, „Aristotle's Theory of Natural Slavery“, in: D. Keyt - F. D. Miller, jr. (vyd.), A Companion to Aristotle's Politics, Oxford -
} 
principiální a dále neredukovatelné (1252b3) předpoklady politického sdružování. Těmi není svazek rozumného pána se silným otrokem, nýbrž spojení rozumu a síly, mužského a ženského, pozorovatelné ve veškeré prírodě.

Př́buznost této pasáže s II. knihou Platónovy Ústavy je zřejmá. Věta „sledovat věci od počátku, jak se přirozeně vyvíjeji“" (ei dé tis ex archés ta fyomena blepseien, 1252a24) prripomíná Sókratův program: „pozorujeme-li vznikání státu prostřednictvím řeči“ (ei gignomenén polin theasaimetha logó, Platón, Resp. II,369a5 n.) - v obou případech je užit stejný optativ možnosti, který naznačuje hypotetickou úvahu, a tedy abstraktní, nikoli historický

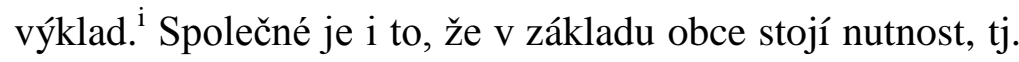
lidská nedostatečnost. Způsob uspokojování této potřebnosti je však odlišný. U Platóna leží v základu obce několik málo (srv. 370d) zaměstnání či úkolů, které musejí být splněny. V Politice se Aristotelés snaží stejnou věc lidskou potřebnost - uchopit syntetičtěji a zároveň ve větší širíi - nikoli pomocí vypočítávání funkčně definovaných úkolů směřujících k zachování života (rolník, švec...), nýbrž vyčleněním dvou typů fundamentálních lidských potřeb - udržení vlastního života a zachování rodu - a jejich svázáním dvěma paradigmatickými vztahy. Takto

Cambridge (Mass.) 1991, str. 146; P. Garnsey, Ideas of slavery from Aristotle to Augustine, Cambridge 1996, str. 119.

${ }^{\mathrm{i}}$ W. Kullmann, „Der Mensch als politisches Lebewesen bei Aristoteles“, str. 96. 
definované „funkce“ aspirují na jednotnější a dialektičtější uchopení základu lidské potřebnosti.

Aristotelés bude stejně jako Platón trvat na tom, že člověk nemůže být bez polis a že polis je nevzniklá, nebot' tyto dvě základní funkce, které jsou přirozené, jsou nějakým způsobem zároveň politické, jak napovídá Aristotelova věta, že polis vznikla pro život (a trvá pro život dobrý) (1252b30). Není tomu tak, že první společenství jsou tady pro život a teprve obec pro dobrý život; ve skutečnosti by člověk bez obce nemohl ani žít. Obec i první společenství se tedy překrývají v úloze udržet člověka a rod při životě, a vzhledem k tomu, že první vztahy jsou zároveň předvedeny jako zakládající, je pravděpodobné, že politický element již nějak formuje i je. ${ }^{i i}$ Právě $\mathrm{k}$ této myšlence mírí Aristotelův výrok, že polis je přirozená, nakolik jsou taková i „první“ společenství (1252b30 n.). ${ }^{\text {iii }}$ Ten nelze považovat za

\footnotetext{
${ }^{i}$ Okolo nich se začne později formulovat první dva př́kazy přirozeného zákona (srv. Tomáš Akvinský, Summa theol. I-II, 94,2). Je však třeba říci, že tato strukturace lidské přirozenosti do dvou úkolů, které tvoří základ politiky, je př́tomna i v Platónově Ústavě, totiž ve dvou prvních Sókratových odvážných politických návrzích („vlnách“) z V. knihy: společný majetek a rozklad tradiční rodiny mírí přesně na řízení těchto dvou základních funkcí. Jinými slovy uživení a rozmnožování se objeví v pozdejjší části dialogu jako jeho hlavní politikum. Je to tedy pouze dialogická forma, která nedovoluje uvést tyto elementy synteticky na jednom místě a nechává je vyvstat teprve postupně v diskusi.

ii Srv. A. Kamp, Die politische Philosophie des Aristoteles und ihre metaphysischen Grundlagen, Freiburg i. Br. - München 1985, str. 102.

iii Adjektivum „prvni““ se, jak je pravděpodobné z kontextu, vztahuje k prvním dvěma nezbytným, a tudíž přirozeným společenstvím, z nichž vzniká domácnost, nikoli tedy $\mathrm{k}$ dědině, která existuje pro jiné úkoly než pouhé přežití.
} 
konečnou Aristotelovu výpověd' v debatě o původu obce v logice textu není ještě konkluzí (tou je až věta 1253a2-5, viz níže), nýbrž pouze uznáním skutečnosti, že polis a první společenství jako nejzákladnější výkony lidského života se ve své přirozenosti, a tudíž i političnosti shodují. Je zřejmé, zřejmé, že v této podobě argument nevyžaduje žádné dějinné líčení a spoléhá - stejně jako Platónova Ústava pouze na evidenci přirozenosti politična samého. Vše ale závisí na tom, zda jsme ochotni již v předpolitické oblasti zahlédnout politickou přirozenost. ${ }^{\text {ii }}$

Aby mohl Aristotelés přijít se svým rozhodným protidémokritovským závěrem, že polis je přirozená a člověk přirozeně politický živočich, a tudíž že kdo žije mimo obec, je bud' zlosyn, nebo bůh (1253a4, 29), musí podat ještě jiný než antropologický argument; musí do jisté míry přijmout genetickou perspektivu (jež je dominantní v „osvícenské“ tradici) a obrátit se kdynamice prvních společenství.

Ze dvou základních úkolů-funkcí je složena domácnost (oikia). Aristotelés ji opět nazve „prvním“ společenstvím: přestože jde v jejím případě vlastně o tytéž

\footnotetext{
${ }^{\mathrm{i}}$ Mělo by být vlastně možné příčinnost ve větě obrátit: první společenství jsou politická, protože taková je i polis.

ii A přijmout tak perspektivu II. knihy Ústavy, v níž je fakt političnosti sdružení lidí Glaukónem a Adeimantem bez dalšího uznán. Aristotelův úkol je v tomto obtížnější, nebot' jeho text není adresován pouze příznivě nakloněným účastníkům platónského rozhovoru.
} 
dva vztahy, o nichž mluvil dosud (nebot' domácnost je „z nich“, ek tútón), nyní je perspektiva změněna a částí již nebudou principy, nýbrž lidské bytosti (srv. 1254b4-8). Aristotelés pojmenovává členy domácnosti tradičním označením „spolustrávníci“ a „spolustolovníci“, které dobře odpovídají úkolu, který plní domácnost, totiž zajištění fyzického přežití (1252b9-15).

$\mathrm{Z}$ domácností vzniká dědina (kómé), která je opět a v jiném smyslu „prvni““, nebot' svým úkolem přesahuje rovinu pouhého živení (1252b14 n.: chréseós heneken mé efémerú). Aristotelés označuje její členy za soukojence, děti a děti dětí a spojuje ji se způsobem královské vlády. Zde se objevuje první explicitní historický poukaz: některé obce (a také Kyklópové) žily dříve pod královskou vládou; u „národů“, tj. barbarů - je tomu tak dosud. Důležité je povšimnout si, že Aristotelés zde paralelně popisuje útvar dědiny, resp. osady, a historicky existující obec se shodným typem vlády: 1) osada jakožto původní dědina byla ovládána královsky (důvodem je rodinný vztah otce a dětí, který zde panuje a který je rovněž odpovědný za sourodost osady a domácnosti, srv. dia tén syngeneian, 1252b21 n.); 2) tím je podobná dřivějším obcím a některým současným „národům“, které žijí ve zřízení podobném dědinám (aniž 
by to ovšem znamenalo, že žijí nepoliticky). ${ }^{\mathrm{i}}$ Prvek vývojové progrese je zde přitom nezpochybnitelný: dědina není již jen pro každodenní potřebu, ale zároveň ještě není dostatečná (jak vyplývá z bezprostředně následujícího určení obce). Zdá se, že dědina, která se někdy interpretům zdá být ve výkladu cizorodým prvkem, hraje roli předchůdného vývojového stadia lidského spolužití shodného s (dřivější a současnou) královskou vládou.

O polis se neříká, jak se jmenují její členové ani jak se v ní vládne (to bude předmětem dalších knih), nýbrž pouze to, že vzniká na konci (tj. na konci jakéhosi vývoje) jako dokonalé společenství. Následnost próté oikia (ve smyslu prvního společenství lidí, kteří se sešli, aby naplnili svoje přirozené potřeby) - próté kómé (ve smyslu společenství, které přirozené potřeby přesahuje) - teleios polis (ve smyslu dokonání předchozích dvou próté) sleduje perspektivu sukcesivního vývoje. Následující věty určující obec jako a) vymezenou tím, že je plně soběstačná $(1252 b 29)^{\mathrm{ii}} \mathrm{a}$ b) přirozenou na základě prvních společenství

\footnotetext{
i Poznatek, že starořecké instituce se shodují se současnými institucemi u barbarů, lze nalézt u Thúkydida $(I, 6,6)$ jako doklad větši rozvinutosti Řeků. Tutéž roli hraje zřejmě i v Aristotelově Politice, kde se opakovaně objevuje v nezměněné formě, a lze jej tedy považovat za další ustálený topos. Jeho součástí bývá představa království jako relativně nevyvinuté formy vlády (Pol. 1263a8, 1285a17-29, 1295a11 n., 1313b10).

ii Slova édé pasés autarkeias $1252 \mathrm{~b} 28 \mathrm{n}$. odkazují na chréseós heneken, b16 a dále $\mathrm{k}$ eis pasan hémeran, b13. Polis je podle nich vyústěním vývoje dvou historických pospolitostí.
} 
(1252b29 n.), upřesňují tuto sukcesi ve dvojím směru: a) obec je soběstačná, ${ }^{i}$ protože má to, co chybí předchozím útvarům složeným z osob, a b) je přirozená ve smyslu, jak je přirozená domácnost a její dva „první“ vztahy, s nimiž má shodný úkol. Tento dvojí smysl „vznikání“ polis ze základních společenství mají potvrdit bezprostředně následující věty (1252b31-1253a1): [ad b] „Obec je totiž jejich konečným cílem a přirozenost je konečný cíl“; [ad a] „Mimoto účel a cíl je to nejlepší; a soběstačnost je i cílem i tím nejlepším. “ii

Teprve poté je možné učinit závěr, že obec je přirozená a že člověk je přirozeně politický živočich. To však již neznamená pouze to, že člověk v obci nachází uspokojení životních potřeb. Zde jde o širší pojem fysis, v němž je rovněž zahrnuto ono historické povědomí o tom, že polis je historický útvar Řeků vzniklý z jistých

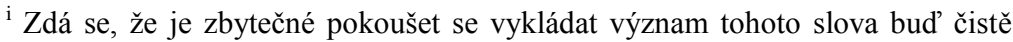
metafyzicky - např̀. jako výraz toho, že polis je chóristheis (A. Kamp, Die politische Philosophie des Aristoteles und ihre metaphysischen Grundlagen, str. 114-115) -, či eticky ve smyslu tezí ze závěru Eth. Nic. (R. Mulgan, Aristotelova politická teorie, str. 33). Je evidentní, že zahrnuje obojí, ale vedle toho také obecně řeckou ideu o historické nadřazenosti polis, která jasně došla výrazu ve výše představené „osvícenské“ tradici.

ii Závěru, že obec je přirozená a soběstačná, je tudíž dosaženo mj. s pomocí spojení dvou pojmů fysis (fysis jako přirozená nutnost, kterou zajišt'ují první společenství, a fysis jako obecné označení konečného stavu vývoje nějaké věci) a soběstačnosti (soběstačnost obce a soběstačnost jako obecný pojem, která je cílem a nejlepším).
} 
předchůdných a primitivnějších forem. ${ }^{\mathrm{i}} \mathrm{V}$ tomto bodě $\mathrm{u}$ Aristotela nepochybně působí osvícenská teze.

Aristotelovým řešením dvou výše uvedených problémů spojených s osvícenským a platónským pojetím vzniku obce však není jednoduše kombinace těchto tradic, nýbrž specifická syntéza. Antropologická struktura a vývoj musejí k sobě být navzájem vztaženy a dialekticky provázány.

Tento vztah je naznačen již $\mathrm{v}$ části, kde se Aristotelés vrací $\mathrm{k}$ antropologicko-biologické argumentaci a doplňuje fundamentální určení člověka o tvrzení, že člověk je „více politický“ než každý stádní živočich (pantos agelaiú zóu mallon, 1253a8), nebot' má logos a může si s ostatními navzájem sdělovat, co je spravedlivé a nespravedlivé. ii Není bez významu, že Aristotelés zde

\footnotetext{
i Proti historickému výkladu se staví W. Kullmann, „Der Mensch als politisches politisches Lebewesen bei Aristoteles", str. 94, podle něhož jde pouze o antropologicko-biologické výroky. S odkazem na metafyzické pojmy př́tomné v I,2 odmítá historický výklad A. Kamp, Die politische Philosophie des Aristoteles und ihre metaphysischen Grundlagen, str. 110. Podobně Mulgan přestože si povšiml historického charakteru líčení na tomto místě - tíhne $\mathrm{k}$ tomu tuto historičnost popírat a zdůrazňovat na jedné straně potřebnost a na druhé straně morální přesah argumentu do Eth. Nic. (R. Mulgan, Aristotelova politická teorie, str. 31-33). Důvod této nechuti interpretů uznat historický prvek Aristotelovy teorie tkví zřejmě v neodstatečné pozornosti k faktu, že Aristotelés navazuje na dosavadní tradici (a to nejen ve smyslu snahy popř́t sofistický protiklad fysis - nomos [tamt., str. 27], nýbrž rovněž ve snaze zahrnout topikou původu obce).

${ }^{i i} \mathrm{Z}$ novověkého hlediska se nám může zdát, že Aristotelés nepotřebuje obojí zdůvodnění - bud' je obec založena v nutnosti, anebo je přirozená tím, že má člověk rozum. V tomto smyslu se můžeme ptát, zda je primárně člověk politický svým logem, nebo svojí potřebou. Pokusy o jednoznačnou odpověd'
} 
používá adjektivum odvozené od slova agelé, které má u Platóna velmi přesný význam - Platón jej používá v Politikovi (261d, 271d; srv. 267b, 276a) a v Zákonech (666e, 680e, 694e, 713d, 735b, 794a, 840d) všude tam, kde způsob lidského politického života kontrastuje bud' se zvířaty, nebo s bohy, anebo kde hovoří o drrívějších historických formách lidského soužití. ${ }^{i}$ Zdá se, že Aristotelés zde používá tentýž terminologický prostředek k odstupňování různých forem přirozeného sdružování, kdy se obec implicitně ukazuje jako završení určitého vývoje. ${ }^{\text {ii }}$ Nejde zde tedy zdaleka pouze o popis biologických vlastností člověka oproti jiným druhům. Adjektivum politické, jakkoli jsou jím označovány také jiné druhy (tř̌eba včely), není primárně biologický titul. Intence tohoto určení mírí mimo biologii, jak vysvítá z otázky, co je vlastně na logu politické. Aristotelova odpověd' je jednoznačná: je to spravedlivé a nespravedlivé a jiné podobné věci, přičemž

však vyznívají nepřesvědčivě: je-li přespř́liš zdůrazněna duchovní stránka (např. ve smyslu Hegela), anebo čistá nutnost (ve smyslu Hobbse), pak ani jedno plně nevystihuje Aristotelův záměr. Je přitom systematicky významné, že v I. knize narážíme na další, analogická napětí: domácnost - polis, hospodářská - politická vláda, otrok-nástroj - otrok-přítel atd. Je zřejmé, že jde o opakování napětí, které je podstatné pro celkový projekt (viz níže).

i V prvním prrípadě člověk žije v polis, zatímco zvírata vagelé; v druhém případě, z hlediska božího vedení, žijí lidé naopak vagelé. To je standardní postup Platónova analogického uvažování. Do rámce téže analogie patří výskyt Leg. VII,794a, kdy jako agelé je označena skupina dětí - opět je zde přítomen implicitní konstrast s vyspělejší pospolitostí dospělých (srv. též Plat. Resp. $\mathrm{V}, 451 \mathrm{c})$.

${ }^{\mathrm{ii}} \mathrm{K}$ rozdílu mezi politika a agelaia srv. Arist. $H A$ I,1,488a7. 
„společenství v těchto věcech vytváří (poiei) domácnost a obec" (1253a18). Logos o spravedlnosti je tedy - mnohem spíše než určením člověka jako druhu - tvůrcem polis. Právě $\mathrm{z}$ této perspektivy - $\mathrm{z}$ hlediska obce, a nikoli člověka - může Aristotelés učinit řadu následujících závěrů, podle nichž je obec původnější než jedinec a že vůči němu celkem (1253a18-29).

Strukturní a dynamické vývojové líčení je tedy v pasáži o $\log u$ úzce provázáno. Polis „vyrůstá“ v tomto komplexním dvojím slova smyslu. Struktura nutnosti a potřebnosti se již na nejzákladnější úrovni obohacuje o logos, který je sice původně antropologickým určením, rovněž ale vědomým tvưrcem obce. ${ }^{i}$

V tomto provázání vyvstávají dvě pojetí fysis (jako normální stav věcí a jako cíl vývoje), a odtud i dvojí pojetí polis (polis jako prirozená struktura lidských potřeb a polis jako historický útvar vyznačující se oproti předchozím stadiím lidského soužití dokonalostí a soběstačností). Předchozí výklad naznačil, že odpovídají dvojímu výkladovému hledisku druhé kapitoly: člověk jako biologický druh a obec jako útvar. Přestože moderní interpreti většinou podléhají pokušení určit jeden ohled jako

\footnotetext{
i To otevírá cestu k pozdějšímu závažnému tvrzení, že lidé by chtěli žít spolu i bez působení nutnosti (Pol. III,6,1278b15).
} 
dominantní, ${ }^{i}$ pro Aristotela si udržuje obojí svůj význam, jak potvrzuje paradoxně znějící shrnutí problematiky na závěr kapitoly: $\mathrm{v}$ lidech je politický pud $\mathrm{k}$ tomuto společenství (tj. polis je tu stále), avšak toto společenství zároveň někdo založil (1253a30).

Jaké cíle sleduje toto podvojné Aristotelovo líčení? Proč se připouští dvojí perspektiva - strukturně-logická i historická - a jaký je smysl autorova manévrování mezi nimi? Naznačili jsme, že oba typy líčení skrývají jisté nebezpečí: rigidita společenského uspořádání spojená s představou filosofa-krále a ideologičnost skrytou v pokrokářské představě vývoje obce. Přestože se ukázalo, že v druhé kapitole nejde o pouhé střídání dvou perspektiv, nýbrž o jejich úzké provázání i $\mathrm{v}$ jednotlivých částech argumentu, zůstává otázka, zda komplexní kombinace obou metod zajistí dostatečnou ochranu před obojím nebezpečím. Teprve podrobnější prozkoumání dvou rozsáhlých pojednání prítomných $\mathrm{v}$ I. knize - totiž o otroku a pánu (I,4-7) a o získávání věcí nutných životu (I,8-11) -

\footnotetext{
${ }^{\mathrm{i}} \mathrm{V}$ moderní interpretaci se zdůrazňují různé prvky: strukturu (W. Kullmann, „Der Mensch als politisches Lebewesen bei Aristoteles“), či vývoj (K. von Fritz - E. Kapp, The Development of Aristotle's Political Philosophy and the Concept of Nature, in: J. Barnes, M. Schofield, R. Sorabji [vyd.], Articles on Aristotle, 2. Etics and Politics, London 1977, str. 113-134). Výklad historického líčení ukázal, že Aristotelés zná genetický výklad, něco vniklo jako dokonalé. Avšak výklad Fritze a Kappa je zde jednostranný - podle nich Aristotelův historický zájem (s heslem fysis) je základem jeho nenormativního zájmu (oproti ranému Protreptikovi). Z úvodu již vysvitlo, že chceme ukázat, že je obojí součástí projektu.
} 
prokáže, že Aristotelovi se daří oběma nebezpečím vyhnout: V prvním př́ípadě ukazuje, že struktura vládnutí není nezměnitelná, a tudíž vládce musí vždy diferencovat, a to jak mezi jednotlivými druhy vlád, tak i v rámci jediné vlády. V druhém př́padě je připraven ukázat, že vývoj je otevřený a nevede k polis a dokonalosti nějak nezadržitelně, přestože však zároveň není nahodilý a lze jej v souladu s fysis a logem utvářet. Proberme nyní tyto dvě otázky, a to $\mathrm{v}$ opačném pořadí.

\section{Přirozenost a pochybení}

Již stálá existence primitivnějšího vývojového stadia osady naznačovala, že vývoj k soběstačné polis není nijak automatický. To, že Aristotelés zná negativní společenskou dynamiku, se však ukazuje podrobněji až při líčení jiné instituce, a to výdělečnictví či získávačství (chrématistiké, resp. ktétiké). ${ }^{i}$ Výdělečnictví přitom nepředstavuje žádnou marginální otázku. Aristotelés neztrácí ze zřetele vůdčí problém zkoumání, jak je určen v první kapitole I. knihy, totiž odlišnost různých druhů vlád $(1252 \mathrm{a} 7-18) .{ }^{\mathrm{ii}}$ Popis

\footnotetext{
i Obojí se používá v Politice I často záměně. Srv. E. Schütrumpf, Aristoteles. Politik I, str. 301.

ii Autor nechce předvést „socioekonomické a antropologické předpoklady“ politického života, jak by očekával moderní interpret vedený představou, že politika má své nutné podmínky $\mathrm{v}$ podobě hospodářského uspořádání (ve smyslu, v jakém nazýváme ekonomii sociální vědou či hovoříme o politickou
} 
hospodářské problematiky má za cíl poukázat na specifičnost politické vlády, a to jednak v odstínění vůči nepolitické oblasti, jednak vykázáním shodných strukturních prvků politična ve fenomenálně určených oblastech každodennosti. Souvislost obojího líčení je dána tím, že Aristotelés při výkladu o výdělečnictví výslovně pokračuje $\mathrm{v}$ analytické metodě, kterou oznámil v první kapitole (kata tén hyfégémenon tropon, 1256a2; srv. 1252a17 n.). Mnohé formální shody výkladu o výdělečnictví v I,8-9 a o obci v I,2 podtrhují, že komplexní úvaha o prrirozeném vzniku, přirozeném vývoji a protipřirozeném úpadku je platná rovněž pro polis.

Paralelnost výkladu o výdělečnictví a vedení domácnosti je potvrzena postupným přitakáním všem třem variantám vztahu obojího, které dává Aristotelés na začátku k úvaze - bud' je výdělečnictví 1) totožné s vedením domácnosti, resp. jeho nejdůležitější složkou (srv. 1253b 12-14), nebo je 2) jeho částí, př́p. je 3) pouze jeho pomocným uměním (1256a3-5). ${ }^{\mathrm{i}}$

ekonomií). Viz H. Arendt, Was ist Politik? Fragmente aus dem Nachlaß, vyd. U. Ludz, München - Zürich 1993, kap. Der Sinn der Politik, str. 35-80.

${ }^{\mathrm{i}}$ Aristotelés sice nejprve odmítne první pojetí, v 11. kapitole po rozlišení dvou různých pojmů výdělečnictví je ale připouští: z hlediska správnosti a nesprávnosti výdělečnictví proti sobě stojí oikonomiké jakožto dobrá a obchodování (kapelistiké) jako špatná chrématistiké. Jinými slovy oikonomiké je zde - tj. z hlediska protikladu špatného a dobrého výdělečnictví - totožná s jeho dobrým druhem. 
V I,8 je však tato otázka nejprve opuštěna ve prospěch úvahy, podle níž z různorodosti způsobů živení lidí vyplývá jejich různý způsob života. Aristotelés zmiňuje kočovníky, lovce, loupežníky, rybáře a zemědělce a všechny je - včetně lupičství - označuje za přirozené

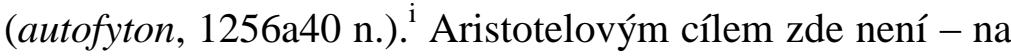
rozdíl od liberální tradice např. u Johna Locka - normativně srovnávat či hodnotit různé způsoby živení (a z toho např́. vyvozovat legitimitu nerovného vlastnictví), nýbrž pouze poukázat na varietu způsobů života, které se u lidí objevují. V obecné (katholú, a18) struktuře péče o potravu není jeden způsob lepší než druhý - i když některé jsou jistě méně obvyklé v porovnání s „nejčastějším“ (pleiston, a38) zemědělstvím. Hledisko je antropologicko-strukturální: základ výdělečného umění, jehož jednu rozvinutou formu můžeme, jak se ukáže později, oprávněně kritizovat, se ukáže jako jednota, když za všemožnou růzností způsobů života rozpoznáme lidskou potřebu (chreia, 1256b6) a nutnost uživení, která jako taková je přirozená. V ní má svůj přirozený původ i majetek (ktésis), jenž je dán přirozeností od dětství, jak paradigmaticky dosvědčuje mateřské mléko, jež je dáno dítěti. Tato teleologická struktura „dávání př́rodou“ je zachována i v dospělosti - lidem jsou stejným

\footnotetext{
i Proto bych argotatoi v řádku 1256a31 nepřekládal jako „nejlínější“ (M. Mráz, Aristotelés. Politika I, str. 67), nýbrž spíše jako „nejnečinnějšíi“, což je spíše popis způsobu života z hlediska lidského ergon (srv. k tomu Eth. Nic. 1097b30).
} 
způsobem dána zvířata a vlastně všechno. Proto je získávání (ktétiké) přirozenou částí hospodářství (oikonomiké), nebot' v něm je nutné si opatřovat zásobu věcí „prospěšných pro společenství obce nebo domácnosti“ i.

Není těžké postřehnout, že postup Aristotelovy argumentace je zde paralelní výkladu v úvodu druhé kapitoly. I zde poukazuje na pririrozenou, antropologicky určenou strukturu potřebnosti a živení, která zakládá vyšší instituce, a to stejně domácnost jako obec. Podobné je i to, že Aristotelés v následující kapitole I,9 překračuje líčení antropologických daností zahrnutím dynamiččěsšího vývojového prvku.

Podle Aristotela existuje jiný druh získávacího umění (genos ktétikés, 1256b40) nazývaný nejčastěji a oprávněně chrématistiké. Oproti prvnímu, přirozenému druhu je jeho původ ve zkušenosti a umění, konkrétně ve směně. Původ směny je $\mathrm{v}$ přirozené skutečnosti ( $\mathrm{ek}$ tou kata fysin, 1257a15 n.), že lidé nemají vždy to, co potřebují, a musí (anankaion, a23) si věci směňovat, jako je tomu dosud u barbarů. V prvním společenství - domácnosti - pro směnu není místo; vzniká teprve tehdy, když se domácnost

\footnotetext{
${ }^{\mathrm{i}}$ Příroda také zároveň přináší přirozené omezení majetku - a to prostřednictvím domácnosti a obce (viz aléthinos plútos ek tútón einai, b30 n.), jejichž prospěch určuje přirozenou míru majetku podle modelu nástroje: majetek je množstvím nástrojů pro správu a prospěch domácnosti a obce (srv. I,4) a žádný nástroj není kolikostně neomezený. Nemá smysl, abychom si pro práci opatřovali desatery hrábě či největší možný krumpáč. Nástroj sám v sobě má hranici kolikosti a velikosti.
} 
rozroste. ${ }^{\mathrm{i}}$ Směna je tedy přirozená prostřednictvím přirozené lidské nedostatečnosti, tj. pouze jako doplněk jiných způsobů obživy (srv. boétheia, 1257a32), nikoli sama o sobě. Proto není součástí přirozeného výdělečnictví, naopak se z ní „logicky“ (kata logon, a31) vyvinula ona jiná chrématistiké, která př̀kračuje přirozenost.

Nutnost totiž přiměla dále lidi zavést (eporisthé, a33 n.) peníze - nomisma, nebot' ne všechny věci, které jsou přirozeně (kata fysin) nutné, lze snadno přenášet. Peníze byly zavedeny dohodou (synethento, 1257a35) jako něco, co je samo užitečné (chrésimón auto) a lze s tím dobře zacházet (chreian eumetacheiriston). Právě zde, u věci, která vyrůstá z přirozené nutnosti, ale je zároveň věcí dohody, lze vystopovat vznik nového druhu chrématistiké jeho původ je $\mathrm{v}$ obchodování (kapélikon), které se zkušeností stále dovedněji (di' empeirias édé technikóteron, $1257 \mathrm{~b} 3$ n.) zaměřuje na vydělávání peněz. To je důvod, proč se zdá, že se chrématistiké nejvíce zabývá penězi, a proč se za bohatství (plúton) považuje množství těchto peněz, nebot' ty jsou jeho mezí. ${ }^{\text {ii }}$

Peníze samy však mez nemají. Aristotelés navazuje na tuto platónskou myšlenku morálně-psychologickým

\footnotetext{
i Aristotelés zde opět rozlišuje mezi synchronním a diachronním kontextem. Směna jako taková nepatří mezi základní antropologické struktury živení, ale vyvinula se ze zkušenosti lidí s jejich nedostatečností.

ii Tento názor se však sám vyvrací právě tím, že peníze jsou pouhou dohodou (nomos, b10) - jejich vlastnictví neubrání člověka před smrtí hlady.
} 
výkladem o žádostivosti (epithymia, 1258a1), která zaměňuje cíl starosti o dobrý život za starost o pouhý život. Žádostivost rovněž nemá meze, a proto chce mít neomezené prostředky. Krajním a nejvíce nepřirozeným (malista para fysin, $1258 \mathrm{~b} 7 \mathrm{n}$.) druhem obchodování je pak lichvářství.

Proti „nenutnému“ výdělečnictví Aristotelés argumentuje teleologicky: mezí každého umění je jeho cíl. Výdělečnictví jako součást či pomocné umění hospodářství má „jiný cíl“ než získávání bohatství (1257b30). Z jiných míst víme, že tímto cílem jsou lidé a jejich ctnost (I,12,1259b18-21; srv. 1258a31 n.). Dá se tedy říci, že rozdíl mezi nutným a nenutným výdělečnictvím leží zde: dbá-li pouze na peníze, je špatné, dbá-li na lidi a jejich ctnost, je přirozené a patř́ k vedení domácnosti, či - jak vysvitne později ${ }^{\mathrm{i}}$ - je s ním dokonce př́mo totožné. ${ }^{\mathrm{ii}}$

Z našeho hlediska je v uvedeném výkladu významná především jeho formální podoba. Postupuje od toho, co vzniklo zcela v souladu s prirozeností a co je antropologickou konstantou, přes vývoj, který sám o sobě není proti pririrozenosti, nebot' je dán nutností a lidskou

\footnotetext{
${ }^{\mathrm{i}}$ Viz pozn. 47.

ii Tezi, že aristotelská ekonomika sleduje především etická (či lépe řečeno morální) hlediska a nepředstavuje samostatnou oblast, která by měla vlastní cíle a pravidla, předložil M. I. Finley, „Aristoteles und ökonomische Analyse“, in: Jahrbuch für Wirtschaftsgeschichte, 1971/II, str. 87-105; a P. Koslowski, Politik und Ökonomie bei Aristoteles, Tübingen 1993, str. 59. Jiného názoru je S. Meikle, „Aristotle and the Political Economy of the Polis“, in: Journal of Hellenic Studies, 99, 1979, 57-73.
} 
nedostatečností, ke vzniku lidských institucí směny a peněz, které jsou výsledkem zkušenosti, umění a smlouvy. Lze ríci, že v této fázi se původní přirozená struktura vyvíjí v přirozeném procesu poháněném potřebností směrem k užitečnosti a soběstačnosti (která podle I,2 vymezuje obec). ${ }^{\text {i }}$ To, že se jedná o pozitivní vývoj, a tudíž Aristotelův Aristotelův př́żnivý pohled na možnosti lidského umu, potvrzuje zmínka o barbarech, kteří již sice znají a užívají směnu, ale ještě ne peníze (srv. 1257a20-22) - barbaři, jak víme, slouží Aristotelovi vždy jako př́iklad nevyspělosti. ${ }^{i i}$ Přesto v tomto vývoji nakonec může nabýt vrchu negativní tendence, způsobená starými známými morálně psychickými motivacemi. Sociální instituce jsou tudíž entitou, která se přirozeně a chvalitebně vyvíjí - to je prvek osvícenského optimismu, který Aristotelés podržuje -, avšak není tomu vždy a nutně. K úpadku dochází tehdy, přestaneme-li dbát na mez a pravý cíl, v tomto př́padě ctnost lidí.

\footnotetext{
i Podle E. Schütrumpfa (Aristoteles. Politik I, str. 323) nejsou peníze pro Aristotela historickým výdobytkem; zajímají jej údajně pouze jako etický problém, o kterém pojednává pod silným platónským vlivem. Schütrumpf zde zcela přehlíží Aristotelovo uznání užitečnosti peněz, a tím i historický kontext úvahy. Zdá se, že zde platí stejné zaslepení jako v př́ípadě popírání historičnosti výkladu o obci (viz pozn. 39). Pozitivně hodnotí první obchod s penězi S. Meikle, „Aristotle and the Political Economy of the Polis“, 61-62; to, že jde o historický výdobytek, uznává i M. I. Finley, „Aristoteles und ökonomische Analyse“, str. 98.
}

ii Srv. pozn. 35 . 
Aristotelés tedy předkládá komplexní výklad geneze lidských institucí - z přirozeného předpokladu (nedostatek) vyplývá program pro lidský um, avšak ten nesmí být ponechán sám sobě, jinak zvítězí žádostivost, která je - jak ukazují střední knihy Politiky - v podobě touhy po bezmezném bohatství příčinou pádu obcí. ${ }^{\mathrm{i}}$ Živení v sobě sice má přirozenou mez (již mají také jiná umění a nástroje), ale tato mez musí být stále znovu nalézána. Ve vzájemné vztaženosti přirozených způsobů lidského života (kojení, lov, loupež, orba...) a ctnostného poznání meze („,už mám dost") spočívá podstata aristotelské ekonomie, pro niž je majetek nástrojem k životu, tj. k praxi (srv. I,4). Zdá se, že jindy těžko uchopitelný rozdíl mezi životem (který může vést k pouhému hromadění peněz) a dobrým životem spočívá právě $v$ této ostražitosti vưči automatismům lidského života.

Výdělečnictví, domácnost a polis jsou výsledkem přirozené potřeby, zároveň jsou však výtvorem, dílem člověka, a jako takové se mohou zdařit i nezdařit. Toto křehké utváření můžeme dokonce nahlížet $\mathrm{v}$ aristotelském kontextu jakéhosi středu - žádoucí není ani setrvání v barbarském (nebo osadním) stadiu soužití, ani překročení mezí přirozeného růstu. Obojí je způsobeno nepochopením cíle vývoje, toho, že obec se má stát nejdokonalejším a

\footnotetext{
${ }^{\text {i }}$ Srv. P. Koslowski, Politik und Ökonomie bei Aristoteles, str. 47-48
} 
„nejmocnějším“ (kyriotaté, 1252a5) společenstvím (k tomu viz níže). Aristotelova tematizace vývojového nezdaru je nejen odpovědí na nebezpečí ideologičnosti přitakání nynějšímu stavu, ale rovněž poukazem na nesprávnost interpretace hovořící o primátu biologického určení člověka, která vlastně neumožňuje rozlišovat mezi dobrým a špatným lidským soužitím, a tudíž znemožňuje jeho zlepšení. ${ }^{\mathrm{i}}$

\section{Nutné a prospěšné}

Zbývá pochopit, jak se Aristotelés vypořádává s druhým nebezpečím, totiž že poznání strukturních podmínek lidského spolužití otevírá nutně cestu jednotné vládě filosofa krále. K tomu je třeba vrátit se $\mathrm{k}$ strukturnímu líčení základů obce a domácnosti v druhé kapitole, prozkoumat zde př́tomný, i když na první pohled neznatelný dynamický prvek a zasadit jej do souvislosti s druhým určujícím pojednáním I. knihy o pánu a otroku.

Výklad o principiálních vztazích z počátku druhé kapitoly, kde je řeč o nutnosti sdružení abstraktních principů mužského a ženského, otrockého a panského, je přerušen překvapivým tvrzením: „Proto totéž přináší prospěch pánu i otroku“ (1252a34). Jak je patrné z jejího

To je fundamentální kritika, s níž se musí vypořádat také „hodnotově neutrální“ výkladové koncepce, jakou předkládají K. von Fritz - E. Kapp, The Development of Aristotle's Political Philosophy and the Concept of Nature. 
obsahu i z formálního spojení, věta nedoplňuje ani neilustruje předchozí výklad. $Z$ formálního hlediska se nezdá vhodné, aby ilustrace principiálního určení poukazem na osoby byla uvedena spojkou „proto“ (dio). Z věcného hlediska se o interpretaci ani ilustraci dosud řečeného nejedná, nebot' věta 1252a34 ř́ká obsahově něco odlišného.

Dosud Aristotelés tvrdil, že sdružení mužského a ženského, rozumného a silného je nutné (ananké, a26). Nyní připojuje, že pro pána a otroka je prospěšné (symferei) „totéž“ (tauto) (srv. 1255b6-7, 9, 10). Nutné a prospěšné jsou však pro Aristotela dvě odlišné věci (1254a21-22). Odpovědět na otázku, co má Aristotelés na mysli oním prospěšným „totéž““, proto není snadné. Nejde o zachování, nebot' to není prospěšné, nýbrž nutné. Nejde ani o „otročit“, „být ovládán“, ani o „vládnout a být ovládán“, o nichž je sice na jiných místech řečeno, že jsou prospěšné (1255a2, 1254a22, 1254b6-7), avšak ,vládnout a být ovládán“ není „totéž“ a „být ovládán“, resp. „otročit“ není pro pána a otroka „totéź“. Jedinou prospěšnou věcí, o níž Aristotelés hovoří a která vyhovuje požadavku vzájemnosti pána a otroka, je ,jakési přátelstvi““, o němž je řeč na pozdějším místě (1255b13). Pán a otrok mohou být v určitých př́ípadech přáteli, což je možnost, která představuje specifický moment v Aristotelově výkladu panství. 
To, že se z nutné sounáležitosti otrockého a panského principu stává přátelský prospěšný vztah dvou lidí, je třeba skutečně pochopit jako změnu kontextu. Střídání dvojího kontextu lze pozorovat rovněž v celku líčení vztahu pána a otroka, přičemž dodržena je i stejná posloupnost. ${ }^{i}$ Nejprve je otrok představen jako nástroj výroby a oduševnělá část pána, která je však svými duševními schopnosti spíše na úrovni domácího zvířete (zejm. I,4-5), později je připuštěno, že otrok je člověk s jistými kognitivními schopnostmi, které mu umožňují vnímat pánův rozum, tvořit s pánem přátelské společenství a pána zavazují $\mathrm{k}$ tomu, aby svou vládou umožnil otroku naplnit své možnosti (zejm. I,13). V Etice Nikomachově je tato podvojnost pojmově zachycena pomocí reduplikačního schématu: přátelství sotrokem není možné jakožto s otrokem, ale jistě jakožto $\mathrm{s}$ člověkem (Eth. Nic. VIII,13,1161b5-9). Rozdíl mezi těmito dvěma kontexty odpovídá rozdílu mezi nutným a prospěšným, jak jej Aristotelés předvádí na zkoumaném místě druhé kapitole I. knihy.

V argumentu Politiky hraje tato podvojnost specifickou roli: jak známo, Aristotelés chce vyvrátit názor prezentovaný v Platónově Politikovi (258e), podle něhož

\footnotetext{
${ }^{\text {i }}$ K následujícímu srv. podrobnější výklad J. Jinek, „Aristotelés o panství: mezi Heideggerem a Gagarinem“, in: Reflexe, 31, 2006, str. 19-44.
} 
neexistuje kvalitativní či druhový rozdíl mezi různými typy vlád (pána, hospodáře, politika a krále). $\mathrm{K}$ tomu potřebuje odlišit různé typy vlád $\mathrm{v}$ rámci obce a domácnosti, což se mu nakonec daří pomocí toho, že poukáže na klíčový rozdíl mezi politickou a nepolitickou vládou (1255b16-20; III,4,1277a34; VIII,2,1337b18 nn.; srv. 1259a 13; 1324a 35 nn.; 1325a 28 nn.; 1333a 3 nn., b 13, 27 nn), ${ }^{\text {i }}$ tj. na rozdíl mezi vládou ve prospěch vládce a vládou ve prospěch ovládaných. Jeho ústřední význam vysvítá ze skutečnosti, že se později stane kritériem pro rozlišení špatných a dobrých zř́zení v III. knize Politiky (III,6,1278b32-40, 1279a17-21).

Předpokladem založení tohoto rozdílu je ovšem předvedení otroka v jeho omezenosti, která ospravedlňuje jeho instrumentální využívání (oproti vládě nad svobodnými, která má za cíl jejich dobro). Hlavní argument I. knihy tedy takříkajíc vyžaduje otroka omezeného a odloučeného od ostatních. Zdůrazněním tohoto kontextu nutnosti a otrokovy odlišnosti se však zároveň Aristotelés dostává do velkých obtíží, má-li prokázat jednotný lidský eidos (I,13,1259b26-28). Pokud Aristotelés nechce připustit, že otrok není člověkem, ani vztah pána vůči otroku nesmí být liččn výhradně jako jednostranný; musí

${ }^{\text {i }}$ G. Bien, Die Grundlegung der politischen Philosophie bei Aristoteles, str. 331. 331. 
být nějak práatelský a musí rovněž nabízet nějaký oboustranný prospěch, jenž v př́padě otroka spočívá $\mathrm{v}$ možnosti charakterového zlepšení (1260b2-6).

Jediným způsobem, jak myslet obojí kontext bezrozporně (otrok je i není plně člověkem), ${ }^{i}$ je tudíž rozlišit synchronní a diachronní dimenzi. Úvaha o vládě nad otrokem se nezastavuje pouze u přirozených vlastností tohoto lidského typu, ale překračuje je úvahou směřující do budoucnosti, v níž se otevírá možnost otrokovy výchovy, zlepšení a dokonce osvobození (srv. VII,10,1330a32-34), tj. vlastně zániku této vlády. ${ }^{\text {ii }} \mathrm{V}$ postavě otroka jako pojítka nutného a prospěšného se tak opakuje forma celého argumentu I. knihy spočívající v napětí mezi předpolitickým (neboli politickým $\mathrm{v}$ širokém smyslu lidské kooperativnosti) i politickým (v úzkém smyslu řecké polis), strukturně daným (přirozeným ve smyslu biologickém) i vyvíjejícím se k lepšímu (prrirozeným ve smyslu teleologickém).

Tuto podvojnost přirozené struktury a přirozeného vývoje, jehož výsledek je však otevřen, již jsme odhalili. Dvojí kontext zkoumání otroka, tj. přirozené struktury, jež se může stát principem odlišení politické a nepolitické vlády, a budoucího vývoje, který překračuje strukturu

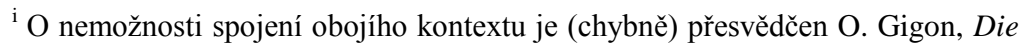
Sklaverei bei Aristoteles, str. 272.

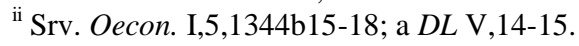


směrem $\mathrm{k}$ ctnosti, však naše poznání upřesňuje $\mathrm{v}$ tom ohledu, že rovněž struktura sama je něčím otevřeným. Již na úrovni nezbytných antropologických základů obce se ukazuje dynamičnost společenské změny. Sama postava otroka se tak nakonec stává prostředkem k rozlišení vlád, tentokrát despotické a tyranské (IV,10,1295a19-23). Vládce, který jakožto hospodář umí rozlišovat mezi různými ovládanými osobami (1252b21) a vůči otroku vystupuje nejprve jako pán (tj. instrumentálně a selektivně), rozlišuje s výhledem do budoucnosti i různý způsob vlády nad tímto jediným člověkem. Výklad o otrokovi tak podtrhuje genetické či prrímo osvícenské prvky Aristotelova výkladu.

Ohled na ovládané, na člověka je hlavním hlediskem politiky i hospodářství. Z vývojové perspektivy do popředí vystupuje péče a výchova, tj. snaha o to učinit ze závislých osob nezávislé občany $(\mathrm{I}, 12-13)$. To je důvod, proč jsou obvyklá království (a jakýkoli jiný typ lidského spolužití uchopovaný podle modelu vztahu otce a dítěte) považovány za relativně primitivní zř́zzení ${ }^{i}$ - neobsahují totiž tuto dynamickou potencialitu k proměně. Historický vývoj k dokonalosti spadá vjedno se schopností politické vlády brát $\mathrm{v}$ úvahu rozdíly mezi jednotlivci $\mathrm{v}$ jejich totožnosti $\mathrm{i}$ různosti.

\footnotetext{
${ }^{\mathrm{i}}$ Viz pozn. 35.
} 
Když Aristotelés hovoří hned v úvodu první kapitoly o obci jako nejmocnější pospolitosti (kyriotaté periechúsa koinónia) a zdůvodňuje to tím, že směřuje k nejvyššímu dobru (kyriotaton agathon, 1252a4-6), pak mírí právě tímto směrem. Obec je nejvíce „zahrnujícím“ společenstvím; tím zahrnovaným je však dobro, které je rovněž nejvyšší patrně ve smyslu zahrnutí plurality různých (i když vzájemně hierarchizovaných) pojetí dober a rozvrhů lidí a společenství (viz Eth. Nic. I,1,1094a6 nn.). ${ }^{i}$ Obec je nejmocnější, nebot' dokáže zohlednit nejvíce takovýchto perspektiv - to z ní činí dokonalou pospolitost. Politiké arché je kyriotaté ne pro počet ovládaných nebo pro největší vědění, nýbrž pro schopnost obsáhnout různorodost. Hospodáŕ je dobrý tehdy, když dokáže při výchově rozlišit mezi členy domácnosti. Ještě lepším se stává, když je $\mathrm{v}$ rámci své role pána schopen rozlišit a vyvážit dva různé postoje k téže ovládané bytosti (otrokovi). Politikem se stává tehdy, když je navíc schopen stejně individuálně a diferencovaně jednat se všemi občany, vůči nimž vstupuje do nejrůznějších vztahů. ${ }^{i i}$ Politik je tak nejvíce „něčeho“ (srv. 1254a11 n.): pánem otroka,

\footnotetext{
Srv. A. Kamp, Die politische Philosophie des Aristoteles und ihre metaphysischen Grundlagen, str. 101-102.

ii Podobně jako u politického přátelství, kde Aristotelés vyžaduje navázat osobní osobní vztah s každým občanem, je to samozřejmě do značné míry utopická pozice - ovšem v pozitivním slova smyslu. Srv. J. Jinek, „Přátelství, dobro, polis. K významu přátelství v celku Aristotelovy praktické filosofie“, in: Studia Neoaristotelica, 8, 2011, str. 72-94.
} 
manželem ženy, otcem dítěte, bratrem bratra, spoluobčanem každého spoluobčana. Předpokladem moci není poznat stabilní strukturu vztahů, nýbrž vstupovat do ní tak, že mohu „být všech“.

\section{Závěr}

Aristotelův úvod do problematiky polis jakožto výklad jejího „růstu“ je komplexním programem, určujícím polis a politično jako svébytnou kombinaci dvojího prvku: 1) stálých strukturních základů daných lidskou potřebností a jejím specificky lidským uspokojováním a 2) historického vývoje ve smyslu utváření polis, chápaného ovšem i v jeho negativních potencialitách. Redukovat tuto teorii pouze na biologické, metafyzické či etické pojmy a principy znamená být nepozorný ke skutečnosti, že Aristotelés postupuje dialektickou metodou vnitřního dialogu, která vždy chce raději zahrnout než vyloučit. Politično je prolínání strukturních principů a vycházení prospěšného z nutného, a to při simultánním pohledu na polis i na člověka. Platónská intuice analogie obce a člověka je zde stále prŕtomna, stejně jako optimismus a dějinné sebevědomí řeckého osvícenství 5.-4. století. 
V kombinaci dvou prvků se však skrývá dvojí nebezpečí: ideologičnost výsledku vývoje a unifikace vlády jediným věděním. Aristotelés se obojímu vyhýbá jednak snahou ukázat, že v polis nejde o to, jak věci (vztahy, vlády) jsou, ale jak budou, a jednak poznatkem, že skutečný vládce se musí ke všem ovládaným vztahovat různě, a to dokonce i $\mathrm{k}$ jediné osobě.

Správné utváření lidských institucí je ve středu jak vůči př́liš překotnému vývoji, tak vůči nevyspělosti lidských institucí. Krajnosti zde spadají vjedno a problém přebujelé i nedokonalé obce je nadále stejný: $\mathrm{v}$ př́padě lichvářství stejně jako v prípadě absolutní vlády barbarského krále (či tyrana) vládne žádostivost a ignoruje se cíl, tj. člověk, kterému se vládne.

To, zda se útvar „politické“ domácnosti vyvine $\mathrm{v}$ dokonalou polis, záleží na schopnosti $\log u$ vzepřít se automatismu lidské žádosti a pečovat o ctnost (v tomto smyslu je lidským dílem i výtvorem př́rody zároveň). Avšak tento způsob omezení přirozené potřebnosti není úkolem jednotného vědění stojícího proti žádostivosti. Omezení musí probíhat vždy s ohledem na různorodost ovládaného prvku. To na úrovni obce znamená být v lidských věcech vždy schopen rozlišovat mezi lidmi, vládami, ale i úkoly jednotlivců. Vládnoucí logos je strukturován a členěn podle ovládaných; rozhodující je 
v politice nikoli vládnoucí, nýbrž podřízený prvek. To je zásada, kterou Aristotelés v Politice drží až do konce.

Otázka a kontext problematiky sufficientia praedicamentorum u Jeronýma Pražského a Robert Alyngton jako oxfordský zdroj jeho odpovědi

\section{Ota Pavlíček}

Mezi texty, které měly určující vliv na povahu diskuzí v tradici západního myšlení, patří přední místo Aristotelovu spisu Kategorie. ${ }^{\mathrm{i}}$ Myslitel ze Stageiry v něm položil základní kameny svého filosofického systému, metafyziky i sémantiky, a Kategorie se i proto staly filosofickým spisem, který je bez ustání komentován, čten i přednášen již od antiky. ${ }^{\text {ii }} \quad \check{e}$ svým interpretům, i díky rozporným

i Aristoteles, Categoriae, český překlad vydal Kříž 1958, spolehlivě do anglického jazyka přeložil Ackrill 1963, vydání obsahují komentáře. Milan Mráz připravoval nový český překlad Kategorií, který by měl z pozůstalosti vyjít v nakladatelství OIKOIMENH spolu se starším českým překladem Profyriových Isagoge. Srov. poznámku 3.

ii $\mathrm{K}$ neoplatonským komentár̆um na Kategorie a jejich vztahům viz text, komentáře a studie v Simplicius 1990a, 1990b, 2001, srov. Chase 2008, ke středověkým spolu s rozsáhlou bibliografií zejména Simplicius 1971, s. IXXXIII, Andrews 2001, Biard, Rosiere-Catach 2003, Bruun, Corti 2005 a Newton 2008, ke druhé scholastice viz např. Bos 2000 a McMahon 2000, kteří uvádějí významnou literaturu i pro diskuse dalších období. Pro otázku umístění Kategorií na prominentní první místo v rámci Aristotelova Organonu spolu s další literaturou viz Pini 2008, s. 145-151. 